\title{
Hospital Cost Shifts As A Result Of Changes In Auto Insurance Regimes
}

\author{
Stephanie Owings-Edwards, (E-mail: owings_s@fortlewis.edu), Fort Lewis College
}

\begin{abstract}
This paper seeks to determine if moving from a no-fault auto insurance system to a tort system will necessarily result in hospitals being faced with more unpaid bills. The answer is found to depend upon legal regulation of the medical insurance industry, the percent of drivers operating without auto insurance, the proportion of drivers who are without medical insurance and the percent of drivers who purchase Med Pay.
\end{abstract}

\section{INTRODUCTION}

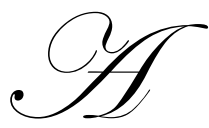

hospital usually collects only a few cents on a dollar's worth of care for patients who have no insurance. As a result, hospitals are very concerned about any change that would increase the percent of uninsured patients they treat. This paper seeks to determine if moving from a no-fault auto insurance system to a tort system will necessarily result in hospitals being faced with more unpaid bills.

The medical community in general has supported no-fault auto insurance and opposed tort. This could be due to the belief, rightly or wrongly held, that a tort system results in a higher proportion of those injured in auto accidents being without insurance to cover the cost of their injuries. However, there are other potential explanations for the medical community's support of no-fault that this paper also reviews.

This paper takes a probabilistic approach to determining whether moving from a no-fault system to a tort system must, necessarily, result in an increase in unpaid hospital bills. Under certain conditions it is found that such a transition can actually reduce the proportion of uninsured patients. Sensitivity analysis confirms these results within the bounds of realistic parameters.

\section{BACKGROUND}

Under a tort liability auto insurance system (also known as "third party insurance"), responsibility for the accident must be determined. Then the at-fault driver's insurance company will pay for the medical bills sustained by the other driver up to the limits of the policy. Under a no-fault system (also known as "first party insurance"), economic damages from injuries sustained in an auto accident are covered by each party's own insurance. This selfinsurance is referred to as personal injury protection (PIP).

States determine under which auto insurance system they wish to operate. As of 1998, thirty-seven states operated under a tort auto insurance regime, ten states operated under no-fault laws and three states were classified as choice states. ${ }^{1}$ Choice states allow each driver to choose whether (s)he wishes to purchase tort insurance or nofault insurance.

All states currently operating under a no-fault regime converted to this system between 1971 and 1976. No state has adopted no-fault since 1976. The primary impetus for moving to no-fault seems to have been high insurance premiums (Harrington, 1994). The states that opted for no-fault also had a higher population density,

\footnotetext{
${ }^{1}$ As of 1998 the no-fault states were: Colorado, Florida, Hawaii, Kansas, Massachusetts, Michigan, Minnesota, New York, and North Dakota. The choice states were: Kentucky, New Jersey, and Pennsylvania.
} 
higher real per capita income, and fewer rural vehicle miles traveled per total vehicle miles traveled than the states that remained under a tort regime (Loughran, 2001). At the time, no-fault was regarded as a system which would speed up payments and lead to more equitable compensation than occurred under a tort system (Schmit and Yeh, 2003).

There are four states that operated under a no-fault system that have since chosen to revert to tort status: Connecticut (no-fault, 1973-1993), Georgia (no-fault, 1975-1991), and Nevada (no-fault, 1974-1980). In 2003 Colorado moved from a no-fault regime to a tort regime.

\section{LITERATURE REVIEW}

There are some papers, based on the economic theory of regulation, which study the special interest groups affected by moving from one auto insurance system to another. Members of the medical community are among these special interest groups. Harrington (1994) considers the time period that states were adopting no-fault (1971 to 1976). He finds that the probability that a state moved from tort to no-fault is higher in states that had a greater number of physicians per capita. However, when Regan (2001) studies Pennsylvania, a choice state, she finds no relationship between the selection of the no-fault option at the county level and the proportion of the population that works in the medical field.

Cummins and Tennyson (1992) observe that no-fault regimes often provide broader and more generous medical benefits than do tort regimes. As a result, non-traditional medical providers (chiropractors, aroma therapists, etc.) will frequently find their services are reimbursable under a no-fault system but not under a tort system. Under these circumstances it is to be expected that non-traditional medical providers will be opposed to any insurance system other than no-fault.

Traditional health care providers also like the generous medical benefits associated with no-fault. In addition, because no-fault insurance decreases the uncertainty associated with payment for care rendered (Regan, 2001) it tends to be favored by medical care professionals. No-fault insurance is often perceived as speeding up the payment process because determination of fault is unnecessary. Although this may not, in fact, be the case, (Schmit and Yeh, 2003) the perception can bias a health care community in favor of no-fault insurance.

Ma and Schmit (2000) find that, controlling for average premium size and other relevant variables, no-fault states have higher levels of uninsured motorists. In a no-fault state, auto insurance will not pay for the medical bills of an uninsured motorist who is injured in an auto accident regardless of who is at fault. In a tort state, auto insurance will pay for the injuries sustained by an uninsured driver if the at-fault driver is insured. Insured drivers who carry uninsured motorist coverage will be covered by their auto insurance in an accident caused by an uninsured motorist. So, under a no-fault system, there are both more uninsured motorists and more categories of uninsured drivers (both at-fault and not-at-fault) whose injuries will not be covered by auto insurance. Although the medical community usually opposes moving from no-fault to tort insurance, the result of such a shift is not necessarily an increase in unpaid medical bills.

The analysis in this paper assumes that there are no more drivers injured in auto accidents as a result of operating under one auto insurance system than another. However, some have claimed that no-fault insurance removes accountability and, as a result, will increase accident rates. There is a long literature (Bruce, 1984; Devlin, 1992; Kochanowski \& Young, 1984; Landes, 1982; Loughran, 2001; McEwin, 1989; Zador, 1986) which attempts to empirically determine whether no-fault insurance does increase driver negligence. The literature is not conclusive. The most recent and thorough approach is found in Loughran (2001). He finds no evidence that the adoption of nofault auto insurance increases auto accident fatalities, the state's accident rate, or the driver negligence rate.

\section{THEORETICAL ANALYSIS}

When determining whether hospitals will be faced with more unpaid debt as a result of moving from a nofault system to a tort system, all four types of accidents must be considered: 
- $\quad$ Insured driver hits insured driver

- Uninsured driver hits uninsured driver

- Uninsured driver hits insured driver

- Insured driver hits uninsured driver

Those who claim transitioning from no-fault to tort will necessarily lead to more unpaid hospital bills may be considering only the first type of accident: insured hitting insured. If this was the only type of accident to occur then hospitals would, unambiguously, lose as a result of moving to a tort regime. But it is estimated that $15 \%$ of drivers in the U.S. are uninsured (Ma and Schmit, 2000). Thus, around 28\% of auto accidents involve at least one uninsured driver.

We also must consider whether there is a probabilistic relationship between choosing to drive without auto insurance and having no medical insurance. That is, if we know an individual has no auto insurance does that make him any more likely than a member of the general population to be without medical insurance? We will consider two extreme, "bookend" cases:

- $\quad$ Case 1: we will assume total independence. That is, knowing that an individual has no auto insurance makes him no more or less likely than a member of the general population to have medical insurance.

- $\quad$ Case 2: we will assume absolute dependence. That is, if we know a driver does not carry auto insurance then we also know that he does not have medical insurance.

There are two different legal conditions we will consider as well:

- $\quad$ Medical insurers deny the claims of those without auto insurance who were involved in auto accidents.

- $\quad$ Medical insurers pay for the injuries sustained by those without auto insurance who were injured in auto accidents.

Which of these conditions pertain depends on state law. For example, in 1998 Colorado health insurers became required by law to provide coverage for the injuries sustained in auto accidents by their members who did not have auto insurance. Prior to that point in time, it was common to find health insurance policies that excluded injuries sustained in an auto accident. This exclusion minimized the health premiums of law-abiding customers. Recall that, in the 1990s, Colorado was a no-fault state. As a result, any driver who obeyed the law and purchased auto insurance had coverage for medical injuries (s)he sustained in an auto accident. A medical insurance provider who paid for the medical bills resulting from an auto accident would be requiring all of its subscribers to pay a higher premium to cover the medical bills of those who chose to disobey the law and drive without insurance.

Scenarios 1, 2 and 3 (pgs. 13-15) consider all of the above mentioned factors. The results demonstrate that moving from no-fault to tort insurance need not necessarily result in an increase in unpaid hospital bills. Approximate parameter values for Colorado are included so that the resulting magnitude of the changes can be gauged.

\section{SENSITIVITY ANALYSIS}

In this section we seek to gauge by how much a single variable would have to change in order to change the results calculated for our representative state, Colorado. This analysis is presented on pages 10-12.

$\underline{\text { Scenario 1: }}$ : considers a system where there is no relationship between the choice to purchase auto insurance and having medical insurance and where medical insurers are allowed to exclude any injuries suffered in an auto accident. 
According to the Rocky Mountain Insurance Information Association, about 25\% of drivers in Colorado chose to purchase Med Pay insurance ${ }^{2}$ when the state reverted to a tort system. If this number goes down over time the gains to the health care system from changing from no-fault to tort will decline. However, even if absolutely no one purchased Med Pay (i.e. if $\mathrm{P}_{5}$ went to one), the health care system would not be hurt from moving from no-fault to tort. National estimates of the percent of the population without medical insurance hover around $15 \%$. If the probability that a driver does not have private medical insurance falls from the initial assumed value of $20 \%$ to $15 \%$ then the gains to the health care system from moving from no-fault to tort increase. However, ceteris paribus, if $27 \%$ or more of the population did not have private medical insurance then the health care system would be faced with more unpaid bills as a result of moving from no-fault to tort. When Colorado was a no-fault state, estimates of the fraction of drivers without auto insurance hovered around $20 \%$. However, if this number fell to the national average $(15 \%)$, the gains to the health care system from moving from no-fault to tort vanish. Given the circumstances of Scenario 1, the medical system will gain as a result of transition from no-fault to tort within all reasonable parameters for Med Pay and the percent of the population which does not have medical insurance. However, relatively small and plausible changes in the percent of drivers without auto insurance could lead to an increase in unpaid hospital bills.

Scenario 2: assumes that medical insurers are forced, by law, to pay the claims of those without auto insurance that are injured in car accidents and that there is no relationship between the choice to purchase auto insurance and having medical insurance.

Under these circumstances, if $80 \%$ of the drivers carried Med Pay then the health care system would not be hurt by the transition from no-fault to tort. But, if any fewer drivers choose to carry Med Pay (recall that only 25\% of drivers purchased Med Pay in Colorado), then hospitals will be faced with more unpaid bills as a result of the auto insurance regime change. An increase in the percent of consumers with medical insurance will decrease the size of the unpaid bills with which hospitals are faced. However, only if everyone had medical insurance, would the health care system not be hurt by transitioning from no-fault to tort. An increase in the percent of drivers with auto insurance will make the transition from no-fault to tort more costly for hospitals. If less than $25 \%$ of drivers were insured, well out of the real-world bounds, only then would the health care system gain from transitioning from tort to no-fault. Given the circumstances of Scenario 2, the health care system is, within all reasonable parameters, hurt by the transition from a no-fault system to tort.

Scenario 3: assumes that all of those who do not carry auto insurance are also without medical insurance.

Under these circumstances, even if no one carried Med Pay, the health care system would still gain from transitioning from no-fault to tort. If more than $33 \%$ of the population did not have medical insurance then the health care system would be hurt by the auto insurance regime change. However, real world, nationwide, estimates of those lacking medical insurance are half this value. If more than $86 \%$ of the population had auto insurance then the health care system would lose as a result of moving from no-fault to tort. Given the circumstances of Scenario 3, the medical system will gain as a result of transition from no-fault to tort within all reasonable parameters for Med Pay and the percent of the population which does not have medical insurance. However, relatively small and plausible changes in the percent of drivers without auto insurance could lead to an increase in unpaid hospital bills.

\section{CONCLUSION}

Although the medical community has generally supported no-fault auto insurance and opposed tort, it is not necessarily true that moving from a no-fault regime to a tort system would increase the size of unpaid bills faced by hospitals. What happens to the proportion of uninsured patients served by hospitals as the result of such a shift depends upon a myriad of factors. These factors include: (a) the proportion of drivers under a tort system that choose Med Pay (b) the proportion of drivers with medical insurance (c) the state law regarding whether medical insurers

2 Med Pay is an optional insurance which drivers who operate under a tort system may purchase. It is first party insurance. That is, its function is similar to personal injury protection under a no-fault system. Med Pay will pay for any medical costs sustained by the insured driver in an auto accident up to the limit of the policy. 
can exclude injuries sustained by drivers without auto insurance (d) the relationship between choosing to drive without auto insurance and being without medical insurance (e) the proportion of drivers without auto insurance (f) the relationship between the proportion of drivers without auto insurance and the auto insurance regime of the state.

Both scenarios 1 and 3 were found to be sensitive to relatively small upward changes in the percent of drivers with auto insurance. In all of the scenarios it was assumed that the percent of drivers with and without car insurance is not affected by moving from a no-fault regime to a tort regime. However, the work of Ma and Schmit (2000) suggests that no-fault states have more uninsured drivers than do tort states. Table 1 (pg. 13) considers the outcomes of all three scenarios when it is assumed that the percent of uninsured drivers is higher in no-fault regimes. Under these circumstances, moving from a no-fault system to a tort system either increases the gains to the medical system or decreases the loss.

Although this paper used Colorado as a representative state, any other state could use this same framework to determine, a priori, if changing auto insurance regimes would result in an increase in unpaid hospital bills.

\section{Variable Definitions}

$\mathrm{P}_{1}=$ probability insured hits insured

$\mathrm{P}_{2}=$ probability uninsured hits uninsured

$\mathrm{P}_{3}=$ probability uninsured hits insured

$\mathrm{P}_{4}=$ probability insured hits uninsured

$\mathrm{P}_{5}=$ probability at-fault, insured, driver does not have Med Pay

$\mathrm{P}_{6}=$ probability at fault driver does not have private medical insurance

$\mathrm{X}=$ number of cars involved in crashes where occupant(s) require medical care

$\mathrm{Y}=$ average cost of treating auto injuries per car

Med Pay: an optional insurance which drivers who operate under a tort system may purchase. It is first party insurance. That is, its function is similar to personal injury protection under a no-fault system. Med Pay will pay for any medical costs sustained by the insured driver in an auto accident up to the limit of the policy.

\section{Estimates of these values for Colorado (1998)}

$80 \%$ of cars are insured, $20 \%$ are uninsured

$\mathrm{P}_{1}=$ probability insured hits insured $=(.8)(.8)=.64$

$\mathrm{P}_{2}=$ probability uninsured hits uninsured $=(.2)(.2)=.04$

$\mathrm{P}_{3}=$ probability uninsured hits insured $=(.2)(.8)=.16$

$\mathrm{P}_{4}=$ probability insured hits uninsured $=(.8)(.2)=.16$

$\mathrm{P}_{5}=$ probability at-fault driver, insured, driver does not have Med Pay $(2003)=.75$

$\mathrm{P}_{6}=$ probability at-fault driver does not have private medical insurance $=.2$

$\mathrm{X}=$ number of cars involved in crashes where occupant(s) require medical care $=52,990$

$\mathrm{Y}=$ average cost of treating auto injuries per car $=\$ 7,800$ 


\section{$\underline{\text { Scenario 1: }}$}

Assumptions:

1. Independence: no relationship between whether an individual carries auto insurance and whether they have medical insurance.

2. Medical insurers deny the claims of those without auto insurance who were involved in auto accidents.

\section{Gains to Health Care System from Shifting from No-Fault to Tort}

\begin{tabular}{|c|c|c|c|}
\hline & No-Fault & Tort & Results \\
\hline Insured hits Insured & PIP pays all bills & $\begin{array}{l}\text { The at-fault driver's liability } \\
\text { will cover the injuries of the } \\
\text { other party. If the at-fault } \\
\text { driver has neither Med Pay } \\
\text { nor private med insurance he } \\
\text { will impose a cost on the } \\
\text { health care system }\end{array}$ & $\begin{array}{l}\left(\mathrm{P}_{1}\right)\left(\mathrm{P}_{5}\right)\left(\mathrm{P}_{6}\right)(\mathrm{X})(\mathrm{Y})= \\
\text { health care system loss from } \\
\text { shifting to Tort }\end{array}$ \\
\hline Uninsured hits Uninsured & $\begin{array}{l}\text { Both are uninsured so } \\
\text { medical costs won't be } \\
\text { covered via auto insurance. } \\
\text { Medical insurance will deny } \\
\text { claims b/c of lack of auto } \\
\text { insurance. }\end{array}$ & $\begin{array}{l}\text { Both are uninsured so } \\
\text { medical costs won't be } \\
\text { covered via auto insurance. } \\
\text { Medical insurance will deny } \\
\text { claims b/c of lack of auto } \\
\text { insurance. }\end{array}$ & $\begin{array}{l}\text { Health care system neither } \\
\text { gains nor loses from shifting } \\
\text { to Tort }\end{array}$ \\
\hline $\begin{array}{l}\text { Uninsured hits Insured; } \\
\text { uninsured @ fault }\end{array}$ & $\begin{array}{l}\text { Insured driver covered by } \\
\text { PIP. Uninsured has no PIP } \\
\text { and medical insurance will } \\
\text { deny claims b/c of lack of } \\
\text { auto insurance. }\end{array}$ & $\begin{array}{l}\text { Insured driver has UM } \\
\text { coverage. Uninsured driver } \\
\text { won't be covered via } \\
\text { medical insurance b/c he has } \\
\text { no auto insurance. }\end{array}$ & $\begin{array}{l}\text { Health care system neither } \\
\text { gains nor loses from shifting } \\
\text { to Tort }\end{array}$ \\
\hline $\begin{array}{l}\text { Insured hits uninsured; } \\
\text { insured @ fault }\end{array}$ & $\begin{array}{l}\text { Insured driver covered by } \\
\text { PIP. Uninsured won't be } \\
\text { covered via medical } \\
\text { insurance b/c he has no auto } \\
\text { insurance }\end{array}$ & $\begin{array}{l}\text { If the insured driver has } \\
\text { neither Med Pay nor private } \\
\text { med insurance then (s)he } \\
\text { will impose a cost on the } \\
\text { health care system. } \\
\text { Uninsured will be covered } \\
\text { under the insured's liability }\end{array}$ & $\begin{array}{l}\left(\mathrm{P}_{4}\right)(\mathrm{X})(\mathrm{Y})- \\
\left(\mathrm{P}_{4}\right)\left(\mathrm{P}_{5}\right)\left(\mathrm{P}_{6}\right)(\mathrm{X})(\mathrm{Y})=\text { health } \\
\text { care system gain from } \\
\text { shifting to tort }\end{array}$ \\
\hline Total & & & $\begin{array}{l}\text { Health care system gain from } \\
\text { shifting to tort }=\left(\mathrm{P}_{4}\right)(\mathrm{X})(\mathrm{Y})- \\
\left(\mathrm{P}_{4}\right)\left(\mathrm{P}_{5}\right)\left(\mathrm{P}_{6}\right)(\mathrm{X})(\mathrm{Y})-\left(\mathrm{P}_{1}\right)\left(\mathrm{P}_{5}\right)( \\
\left.\mathrm{P}_{6}\right)(\mathrm{X})(\mathrm{Y})= \\
\mathrm{XY}\left[\mathrm{P}_{4}-\left(\mathrm{P}_{4} \mathrm{P}_{5} \mathrm{P}_{6}\right)-\left(\mathrm{P}_{1} \mathrm{P}_{5} \mathrm{P}_{6}\right)\right] \\
\text { This value will be positive if } \\
\mathrm{P}_{4}>\mathrm{P}_{5} \mathrm{P}_{6}\left(\mathrm{P}_{4}+\mathrm{P}_{1}\right) \\
\text { For Colorado, under these } \\
\text { circumstances, the health } \\
\text { care system gain would } \\
\text { approximated be } \\
\$ 16,532,880\end{array}$ \\
\hline
\end{tabular}




\section{Scenario 2:}

Assumptions:

1. Independence: no relationship between whether an individual carries auto insurance and whether they have medical insurance.

2. Medical insurers pay the claims of those without auto insurance who were involved in auto accidents.

Costs Imposed on Health Care System from Shifting from No-Fault to Tort

\begin{tabular}{|c|c|c|c|}
\hline & No-Fault & Tort & Results \\
\hline Insured hits Insured & PIP pays all bills & $\begin{array}{l}\text { The at-fault driver's liability } \\
\text { will cover the injuries of the } \\
\text { other party. If the at-fault } \\
\text { driver has neither Med Pay } \\
\text { or private med insurance he } \\
\text { will impose a cost on the } \\
\text { health care system }\end{array}$ & $\begin{array}{l}\left(\mathrm{P}_{1}\right)\left(\mathrm{P}_{5}\right)\left(\mathrm{P}_{6}\right)(\mathrm{X})(\mathrm{Y})= \\
\text { health care system loss from } \\
\text { shifting to Tort }\end{array}$ \\
\hline Uninsured hits Uninsured & $\begin{array}{l}\text { Both are uninsured so } \\
\text { medical costs won't be } \\
\text { covered via auto insurance. } \\
\text { Medical insurance will pay } \\
\text { claims for those who have it. }\end{array}$ & $\begin{array}{l}\text { Both are uninsured so } \\
\text { medical costs won't be } \\
\text { covered via auto insurance. } \\
\text { Medical insurance will pay } \\
\text { claims for those who have it }\end{array}$ & $\begin{array}{l}\text { Health care system neither } \\
\text { gains nor loses from shifting } \\
\text { to Tort }\end{array}$ \\
\hline $\begin{array}{l}\text { Uninsured hits Insured; } \\
\text { uninsured @ fault }\end{array}$ & $\begin{array}{l}\text { Insured driver covered by } \\
\text { PIP. Uninsured driver will be } \\
\text { covered by med insurance if } \\
\text { (s)he has it. }\end{array}$ & $\begin{array}{l}\text { Insured driver has UM } \\
\text { coverage. Uninsured driver } \\
\text { will be covered by med } \\
\text { insurance if (s)he has it. }\end{array}$ & $\begin{array}{l}\text { Health care system neither } \\
\text { gains nor loses from shifting } \\
\text { to Tort }\end{array}$ \\
\hline $\begin{array}{l}\text { Insured hits uninsured; } \\
\text { insured @ fault }\end{array}$ & $\begin{array}{l}\text { Insured driver covered by } \\
\text { PIP. Uninsured will be } \\
\text { covered via medical } \\
\text { insurance if }(\mathrm{s}) \text { he has it. }\end{array}$ & $\begin{array}{l}\text { If the insured driver has } \\
\text { neither Med Pay nor private } \\
\text { med insurance then (s)he } \\
\text { will impose a cost on the } \\
\text { health care system. } \\
\text { Uninsured will be covered } \\
\text { under the insured's liability }\end{array}$ & $\begin{array}{l}\left(\mathrm{P}_{4}\right)\left(\mathrm{P}_{6}\right)(\mathrm{X})(\mathrm{Y})- \\
\left(\mathrm{P}_{4}\right)\left(\mathrm{P}_{5}\right)\left(\mathrm{P}_{6}\right)(\mathrm{X})(\mathrm{Y})=\text { health } \\
\text { care system gain from } \\
\text { shifting to tort }\end{array}$ \\
\hline Total & & & $\begin{array}{l}\text { Health care system gain from } \\
\text { shifting to tort }= \\
\left(\mathrm{P}_{4}\right)\left(\mathrm{P}_{6}\right)(\mathrm{X})(\mathrm{Y})- \\
\left(\mathrm{P}_{4}\right)\left(\mathrm{P}_{5}\right)\left(\mathrm{P}_{6}\right)(\mathrm{X})(\mathrm{Y})-\left(\mathrm{P}_{1}\right)\left(\mathrm{P}_{5}\right)( \\
\left.\mathrm{P}_{6}\right)(\mathrm{X})(\mathrm{Y})= \\
\mathrm{XY} \mathrm{P}_{4} \mathrm{P}_{6}-\left(\mathrm{P}_{4} \mathrm{P}_{5} \mathrm{P}_{6}\right)- \\
\left.\left(\mathrm{P}_{1} \mathrm{P}_{5} \mathrm{P}_{6}\right)\right] \\
\text { This value will be positive if } \\
\mathrm{P}_{4} \mathrm{P}_{6}>\mathrm{P}_{5} \mathrm{P}_{6}\left(\mathrm{P}_{4}+\mathrm{P}_{1}\right) \\
\text { For Colorado, the health care } \\
\text { system loss is approximated } \\
\text { to be } \$ 36,372,336\end{array}$ \\
\hline
\end{tabular}

\section{Scenario 3:}

\section{Assumptions:}

1. Perfect dependence: anyone who doesn't carry auto insurance also does not have medical insurance

2. It does not matter whether medical insurers deny or cover the claims of those without auto insurance who were involved in auto accidents. 
Costs Imposed on Health Care System from Shifting from No-Fault to Tort

\begin{tabular}{|c|c|c|c|}
\hline & No-Fault & Tort & Results \\
\hline Insured hits Insured & PIP pays all bills & $\begin{array}{l}\text { The at-fault driver's liability } \\
\text { will cover the injuries of the } \\
\text { other party. If the at-fault } \\
\text { driver has neither Med Pay } \\
\text { or private med insurance he } \\
\text { will impose a cost on the } \\
\text { health care system }\end{array}$ & $\begin{array}{l}\left(\mathrm{P}_{1}\right)\left(\mathrm{P}_{5}\right)\left(\mathrm{P}_{6}\right)(\mathrm{X})(\mathrm{Y})= \\
\text { health care system loss from } \\
\text { shifting to Tort }\end{array}$ \\
\hline Uninsured hits Uninsured & $\begin{array}{l}\text { Both are uninsured so } \\
\text { medical costs won't be } \\
\text { covered via auto insurance. } \\
\text { Since they don't have auto } \\
\text { insurance we know neither } \\
\text { has medical insurance }\end{array}$ & $\begin{array}{l}\text { Both are uninsured so } \\
\text { medical costs won't be } \\
\text { covered via auto insurance. } \\
\text { Since they don't have auto } \\
\text { insurance we know neither } \\
\text { has medical insurance }\end{array}$ & $\begin{array}{l}\text { Health care system neither } \\
\text { gains nor loses from shifting } \\
\text { to Tort }\end{array}$ \\
\hline $\begin{array}{l}\text { Uninsured hits Insured; } \\
\text { uninsured @ fault }\end{array}$ & $\begin{array}{l}\text { Insured driver covered by } \\
\text { PIP. We know uninsured } \\
\text { driver won't be covered by } \\
\text { med insurance since (s)he } \\
\text { doesn't have auto insurance. }\end{array}$ & $\begin{array}{l}\text { Insured driver has UM } \\
\text { coverage. We know } \\
\text { uninsured driver won't be } \\
\text { covered by med insurance } \\
\text { since (s)he doesn't have auto } \\
\text { insurance. }\end{array}$ & $\begin{array}{l}\text { Health care system neither } \\
\text { gains nor loses from shifting } \\
\text { to Tort }\end{array}$ \\
\hline $\begin{array}{l}\text { Insured hits uninsured; } \\
\text { insured @ fault }\end{array}$ & $\begin{array}{l}\text { Insured driver covered by } \\
\text { PIP. We know uninsured } \\
\text { driver won't be covered by } \\
\text { med insurance since (s)he } \\
\text { doesn't have auto insurance. }\end{array}$ & $\begin{array}{l}\text { The insured driver will have } \\
\text { med insurance since (s)he } \\
\text { has auto insurance. } \\
\text { Uninsured will be covered } \\
\text { under the insured's liability }\end{array}$ & $\begin{array}{l}\left(\mathrm{P}_{4}\right)(\mathrm{X})(\mathrm{Y})=\text { health care } \\
\text { system gain from shifting to } \\
\text { tort }\end{array}$ \\
\hline Total & & & $\begin{array}{l}\text { Health care system gain from } \\
\text { shifting to tort }= \\
\left(\mathrm{P}_{4}\right)(\mathrm{X})(\mathrm{Y})-\left(\mathrm{P}_{1}\right)\left(\mathrm{P}_{5}\right)( \\
\left.\mathrm{P}_{6}\right)(\mathrm{X})(\mathrm{Y})= \\
\mathrm{XY}\left[\mathrm{P}_{4}-\left(\mathrm{P}_{1} \mathrm{P}_{5} \mathrm{P}_{6}\right)\right] \\
\text { This value will be positive if } \\
\mathrm{P}_{4}>\mathrm{P}_{1} \mathrm{P}_{5} \mathrm{P}_{6} \\
\text { For Colorado, the health care } \\
\text { system gain is approximated } \\
\text { to be } \$ 26,452,608\end{array}$ \\
\hline
\end{tabular}

\section{$\underline{\text { Scenario } 1 \text { Sensitivity Analysis }}$}

\section{Assumptions:}

1. Independence: no relationship between whether an individual carries auto insurance and whether they have medical insurance.

2. Medical insurers deny the claims of those without auto insurance who were involved in auto accidents.

\begin{tabular}{|c|c|c|c|c|c|c|c|c|c|c|}
\hline row & prob. insured & prob. unins. & p1 & p2 & p3 & p4 & p5 & p6 & p5p6(p4 + p1) & gap \\
\hline 1 & 0.8 & 0.2 & 0.64 & 0.04 & 0.16 & 0.16 & 0.75 & 0.2 & 0.12 & 0.04 \\
\hline 2 & 0.8 & 0.2 & 0.64 & 0.04 & 0.16 & 0.16 & 0.95 & 0.2 & 0.152 & 0.008 \\
\hline 3 & 0.8 & 0.2 & 0.64 & 0.04 & 0.16 & 0.16 & 1 & 0.2 & 0.16 & 0 \\
\hline 4 & 0.8 & 0.2 & 0.64 & 0.04 & 0.16 & 0.16 & 0.75 & 0.15 & 0.09 & 0.07 \\
\hline 5 & 0.8 & 0.2 & 0.64 & 0.04 & 0.16 & 0.16 & 0.75 & 0.27 & 0.162 & -0.002 \\
\hline 6 & 0.85 & 0.15 & 0.7225 & 0.0225 & 0.1275 & 0.1275 & 0.75 & 0.2 & 0.1275 & 0 \\
\hline
\end{tabular}


gap $=\mathrm{p} 4-\mathrm{p} 5 \mathrm{p} 6(\mathrm{p} 4+\mathrm{p} 1)$; if the gap is positive then the health care system gains from moving to tort

row 1: baseline

row 2: increase p5 (prob. at-fault driver does not have Med Pay) RESULT: gap narrows

row 3: set p5 (prob. at-fault driver does not have Med Pay) equal to 1. RESULT: gap equals zero

row 4: decrease p6 (prob. at fault driver does not have med insurance: $15 \%$ is the national average) RESULT: gap grows

row 5: increase p6 (prob. at fault driver does not have med insurance) to 27\% RESULT: gap becomes negative

row 6: increase probability insured ( $85 \%$ is the national average) RESULT: gap drops to zero

\section{$\underline{\text { Scenario } 2 \text { Sensitivity Analysis }}$}

\section{Assumptions:}

1. Independence: no relationship between whether an individual carries auto insurance and whether they have medical insurance.

2. Medical insurers pay the claims of those without auto insurance who were involved in auto accidents.

\begin{tabular}{|r|r|r|r|r|r|r|r|r|r|r|}
\hline row & prob. insured & prob. unins. & P1 & P2 & P3 & P4 & P5 & P6 & p5p6(p4 + p1) & gap \\
\hline 1 & 0.8 & 0.2 & 0.64 & 0.04 & 0.16 & 0.16 & 0.75 & 0.2 & 0.12 & -0.088 \\
\hline 2 & 0.8 & 0.2 & 0.64 & 0.04 & 0.16 & 0.16 & 0.2 & 0.2 & 0.032 & 0 \\
\hline 3 & 0.8 & 0.2 & 0.64 & 0.04 & 0.16 & 0.16 & 0.75 & 0.15 & 0.09 & -0.066 \\
\hline 4 & 0.8 & 0.2 & 0.64 & 0.04 & 0.16 & 0.16 & 0.75 & 0 & 0 & 0 \\
\hline 5 & 0.85 & 0.15 & 0.7225 & 0.0225 & 0.1275 & 0.1275 & 0.75 & 0.2 & 0.1275 & -0.102 \\
\hline 6 & 0.25 & 0.75 & 0.0625 & 0.5625 & 0.1875 & 0.1875 & 0.75 & 0.2 & 0.0375 & 0 \\
\hline
\end{tabular}

gap $=\mathrm{p} 4 \mathrm{p} 6-\mathrm{p} 5 \mathrm{p} 6(\mathrm{p} 4+\mathrm{p} 1)$; if the "gap" is negative then the health care system loses from switching from NF to tort row 1: baseline

row 2: decrease p5 (prob. at-fault driver does not have Med Pay) RESULT: gap drops to zero

row 3: decrease p6 (prob. at fault driver does not have med insurance: 15\% is the national average) RESULT: gap narrows:

health care system faces smaller losses

row 4: decrease P6 (prob. at-fault driver does not have med insurance) to zero. RESULT: gap drops to zero

row 5: increase probability insured ( $85 \%$ is the national average) RESULT: gap widens: health care system faces larger losses row 6: decrease probability insured to $25 \%$. RESULT: gap goes to zero

\section{$\underline{\text { Scenario } 3 \text { Sensitivity Analysis }}$}

\section{Assumptions:}

1. Perfect dependence: anyone who doesn't carry auto insurance also does not have medical insurance

2. It does not matter whether medical insurers deny or cover the claims of those without auto insurance who were involved in auto accidents.

\begin{tabular}{|r|r|r|r|r|r|r|r|r|r|r|r|}
\hline row & prob. insured & prob. unins. & P1 & P2 & P3 & P4 & P5 & P6 & p1p5p6 & gap \\
\hline 1 & 0.8 & 0.2 & 0.64 & 0.04 & 0.16 & 0.16 & 0.75 & 0.2 & 0.096 & 0.064 \\
\hline 2 & 0.8 & 0.2 & 0.64 & 0.04 & 0.16 & 0.16 & 1 & 0.2 & 0.128 & 0.032 \\
\hline 3 & 0.8 & 0.2 & 0.64 & 0.04 & 0.16 & 0.16 & 0.75 & 0.33 & 0.1584 & 0.0016 \\
\hline 4 & 0.87 & 0.13 & 0.7569 & 0.0169 & 0.1131 & 0.1131 & 0.75 & 0.2 & 0.113535 & -0.000435 \\
\hline
\end{tabular}


gap $=\mathrm{p} 4-\mathrm{p} 1 \mathrm{p} 5 \mathrm{p} 6$; if the gap is positive then the health care system gains from moving from no-fault to tort

row 1: baseline

row 2: increase p5 (prob. at-fault driver does not have Med Pay) RESULT: gap narrows: health care system gains less than before from transition

row 3: increase p6 (prob. at fault driver does not have med insurance: 15\% is the national average) RESULT: gap shrinks: health care system gains less from transition

row 4: increase probability insured ( $85 \%$ is the national average) RESULT: gap becomes negative

\section{$\underline{\text { Table } 1}$}

Assuming the percent of uninsured drivers is higher under no-fault than under tort implies: $\mathrm{P}_{1 \mathrm{NF}}<\mathrm{P}_{1 \mathrm{~T},} \mathrm{P}_{2 \mathrm{NF}}>\mathrm{P}_{2 \mathrm{~T}}, \mathrm{P}_{3 \mathrm{NF}}>\mathrm{P}_{3 \mathrm{~T}}$, and $\mathrm{P}_{4 \mathrm{NF}}>\mathrm{P}_{4 \mathrm{~T}}$.

\begin{tabular}{|l|l|l|}
\hline & $\begin{array}{l}\text { Assuming no change in the percent of uninsured } \\
\text { drivers as the system moves from no-fault to tort } \\
\text { (from previous analysis) }\end{array}$ & $\begin{array}{l}\text { Assuming the percent of uninsured drivers is } \\
\text { higher under no-fault }\end{array}$ \\
\hline Scenario 1 & $\begin{array}{l}\text { Health care system gain from shifting to tort }= \\
\mathrm{XY}\left[\mathrm{P}_{4}-\left(\mathrm{P}_{4} \mathrm{P}_{5} \mathrm{P}_{6}\right)-\left(\mathrm{P}_{1} \mathrm{P}_{5} \mathrm{P}_{6}\right)\right]\end{array}$ & $\begin{array}{l}\text { Health care system gain from shifting to tort }= \\
\mathrm{XY}\left[\mathrm{P}_{4 N F}-\left(\mathrm{P}_{4 \mathrm{~T}} \mathrm{P}_{5} \mathrm{P}_{6}\right)-\left(\mathrm{P}_{1 \mathrm{~T}} \mathrm{P}_{5} \mathrm{P}_{6}\right)\right]\end{array}$ \\
\hline Scenario 2 & $\begin{array}{l}\text { Health care system gain from shifting to tort }= \\
\mathrm{XY}\left[\mathrm{P}_{4} \mathrm{P}_{6}-\left(\mathrm{P}_{4} \mathrm{P}_{5} \mathrm{P}_{6}\right)-\left(\mathrm{P}_{1} \mathrm{P}_{5} \mathrm{P}_{6}\right)\right] \\
(\text { This is a negative number for all reasonable } \mathrm{P} \\
\text { values })\end{array}$ & $\begin{array}{l}\text { Health care system gain from shifting to tort }= \\
\mathrm{XY}\left[\mathrm{P}_{4 N \mathrm{~N}} \mathrm{P}_{6}-\left(\mathrm{P}_{4 \mathrm{~T}} \mathrm{P}_{5} \mathrm{P}_{6}\right)-\left(\mathrm{P}_{1 T} \mathrm{P}_{5} \mathrm{P}_{6}\right)\right] \\
(\text { This is a smaller negative number for all reasonable } \\
\mathrm{P} \text { values })\end{array}$ \\
\hline Scenario 3 & $\begin{array}{l}\text { Health care system gain from shifting to tort }= \\
\mathrm{XY}\left[\mathrm{P}_{4}-\left(\mathrm{P}_{1} \mathrm{P}_{5} \mathrm{P}_{6}\right)\right]\end{array}$ & $\begin{array}{l}\text { Health care system gain from shifting to tort }= \\
\mathrm{XY}\left[\mathrm{P}_{4 N F}-\left(\mathrm{P}_{1 \mathrm{~T}} \mathrm{P}_{5} \mathrm{P}_{6}\right)\right]\end{array}$ \\
\hline
\end{tabular}

\section{References:}

1. Bruce, Christopher, J., 1984. "The Deterrent Effects of Automobile Insurance and Tort Law: A Survey of the Empirical Literature," Law and policy, 6: 67.

2. Cummins, J. David and Sharon Tennyson, 1992. "Controlling Automobile Insurance Costs," Journal of Economic Perspectives, 6: 95.

3. Devlin, Rose Anne, 1992. "Liability Versus No-Fault Automobile Insurance Regimes: An Analysis of the Experience in Quebec," Contributions to Insurance Economics, Georges Dionne, ed., Boston: Kluwer Academic Publishers.

4. Harrington, Scott E., 1994. "State Decisions to Limit Tort Liability: An Empirical analysis of No-Fault Automobile Insurance Laws," The Journal of Risk and Insurance, 61: 276.

5. Kochanowski, Paul S. and Madelyn V. Young, 1984. "Deterrent Aspects of No-Fault Automobile Insurance: Some Empirical Findings.” Journal of Risk and Insurance, 52: 259.

6. Landes, Elisabeth, 1982. "Insurance, Liability, and Accidents: A Theoretical and Empirical Investigation of the Effect of No-Fault Accidents," Journal of Law and Economics, 25: 49.

7. Loughran, David S., 2001. "The Effect of No-fault Automobile Insurance on Driver Behavior and Automobile Accidents in the United States," Santa Monica, CA: RAND.

8. Ma, Yu-Luen and Joan T. Schmit, 2000. "Factors Affecting the Relative Incidence of Uninsured Motorists Claims," The Journal of Risk and Insurance, 67: 281.

9. McEwin, R. Ian, 1989. "No-Fault and Road Accidents: Some Australasian Evidence," International Review of Law and Economics, 9: 13.

10. Regan, Laureen, 2001. "Determinants of the Selection of Full or Limited Tort Auto Insurance in Pennsylvania: An Empirical Analysis," The Economics and Politics of Choice No-Fault Insurance, Edward L. Lascher, Jr. and Michael R. Powers, eds., Boston: Kluwer Academic Publishers.

11. Rocky Mountain Insurance Information Association, 2004. Colorado's Transition from No-Fault to Tort Auto Insurance.

12. Schmit, Joan T., and Jia-Hsing Yeh, 2003. "An Economic Analysis of Auto compensation Systems: Choice Experience from New Jersey and Pennsylvania,” The Journal of Risk and Insurance, 70: 601.

13. Volger, Sally, 7/27/2004. <sally_volger@Ahtnem.com>. Personal email communication re. medical insurance laws and uninsured motorists in Colorado. Anthem Blue Cross Blue Shield of Colorado.

14. Zador, Paul, and Adrian Lund, 1986. "Re-Analysis of the Effect of No-Fault Auto Insurance on Fatal Crashes," Journal of Risk and Insurance, 53: 226. 